\title{
Productivity of winter maize as affected by varieties and
}

\section{fertilizer levels}

\author{
Bishnu Hari Adhikary, Bandhu Raj Baral, \& Jiban Shrestha \\ National Maize Research Program, Rampur, Chitwan, Nepal.
}

\begin{abstract}
Grain yield production of maize is greatly affected by varieties and fertilizer levels. This study was conducted to determine the effects of different rates of fertilizers (nitrogen, phosphorus, potassium fertilizers and farmyard manures) on grain yield and yield attributing traits of different maize varieties during winter seasons of 2009/10 and 2010/011 at the research farm of National Maize Research Program, Rampur, Chitwan, Nepal. Six levels of fertilizers [Control (Zero fertilizer), FYM @ 10 t/ha, FYM@10 t/ha plus 60:30 20 kg NPK/ha, FYM@ 10 t/ha plus 120: 60: 40 kg NPK/ha, FYM@ 10 t/ha plus 180: 90: $60 \mathrm{~kg} \mathrm{NPK} / \mathrm{ha}$, and 120: 60: $40 \mathrm{~kg} \mathrm{NPK} / \mathrm{ha}$ ] and four maize varieties (Rampur Composite, Manakamana-4, Across9942 × Across 9944 and S99TLYQ-B) were evaluated in randomized complete block design with three replications. The results showed that grain yield was non-significant for maize genotypes but the fertilizers levels were highly significant for grain yield. Rampur Composite produced the highest grain yield ( $5195 \mathrm{~kg} / \mathrm{ha})$, followed by Manakamana-4 (5074 kg/ha), Across $9942 \times$ Across9944 (5052 kg/ha) and S99TLYQ-B (4789 kg/ha) with the application of NPK 180: $90: 60 \mathrm{~kg} / \mathrm{ha}$ plus FYM $10 \mathrm{t} / \mathrm{ha}$. This information is useful in generating suitable fertilization packages for obtaining higher grain yield of maize varieties.
\end{abstract}

\section{Article History}

Received 30 March 2020

Accepted 15 June 2020

Keyword

Fertilizer and manures, Maize genotypes,

Grain yield, Yield attributing traits.

\section{Introduction}

Maize (Zea mays L.) has the highest productivity per unit area as compared to other cereal crops. It ranked third among the cereal crops in the world after wheat and rice. In Nepal, it is the second most important staple food crop in terms of both area and production after rice but it is the first staple crop for hills. In Nepal, maize has been grown over an area of 954158 hectares in 2017/18 with a production of 2555847 tons and a productivity of 2.67 $\mathrm{t} / \mathrm{ha}$ (MoALD, 2018). The production of maize is low as compared to other countries.

The production can be improved or increased through adequate nutrient management practices. Maize being the heavy feeder crop, a balanced dose of organic and inorganic application of fertilizer is needed for increased productivity. Fertilizer management is crucial for maize cultivation (Baral et al., 2015). Manures and fertilizers both play an important role in maize cultivation. $\mathrm{N}$ is usually applied in 3 equal splits at sowing, knee-high stage and tasseling stage. als/ha of grain yields and likewise, it can be reduced or 
increased as per its expected yield. Phosphorus $(\mathrm{P})$ is the next most important plant nutrient after $\mathrm{N}$ which is found difficult in most soils. It has a beneficial effect on root growth and plant health. This nutrient should be applied initially at the early stage because of its low solubility in water. It should be applied in a moist zone to be transformed quickly for early absorption by the plant. The dose of $P$ should be balanced with the dose of $N$ applied. Potassium is considered to be the 3rd most essential fertilizer element, it is not found deficient in most of the soils. It is essential for the vigorous growth of the plant and for so many other metabolic activities.K application through fertilizers has been responding satisfactorily (Regmi et al., 2002). Maize being a high nutrient mining crop it needs a higher amount of NPK for its economic production. Farmers applying 20-25 t/ha of compost/FYM (manures) are not sufficient to replenish the harvested nutrients and hence need a sufficient amount of mineral fertilizer addition with heavy manure application (Joshy, 1997). Adhikary et al. (2001) reported that the highest maize grain yield $(4.65 \mathrm{t} / \mathrm{ha}$ ) could be obtained when the crop is fertilized by $20 \mathrm{t}$ of compost plus 100: 75: $40 \mathrm{~kg} / \mathrm{ha}$ of $\mathrm{N}, \mathrm{P}_{2} \mathrm{O}_{5}$, and $\mathrm{K}_{2} \mathrm{O}$ in the acidic soils of Malepatan, Pokhara. Adhikary and Ranabhat (Adhikary and Ranabhat, 2004) studied the economics of manure and fertilizer application on maize production and concluded that most economic dose of fertilizer was 100: 75: $40 \mathrm{~kg} \mathrm{~N}, \mathrm{P}_{2} \mathrm{O}_{5}$ and $\mathrm{K}_{2} \mathrm{O} /$ ha from inorganic sources and $20 \mathrm{t} / \mathrm{ha}$ of compost that contained $280 \mathrm{~kg} \mathrm{~N}, 184 \mathrm{~kg} \mathrm{P}_{2} \mathrm{O}_{5}$ and $216 \mathrm{~kg} \mathrm{~K} \mathrm{~K}_{2} \mathrm{O}$. Adhikary et al. (2007) studied the effect of fertilizer and agricultural lime on grain yield of different maize genotypes in the Western hills of Nepal and reported that improved maize variety (Manakamana-1) did not differ in grain production with the local variety when supplied with fertilizers at 60: $30: 30 \mathrm{~kg} \mathrm{~N}, \mathrm{P}_{2} \mathrm{O}_{5}$ and $\mathrm{K}_{2} \mathrm{O}$ and $4 \mathrm{t} / \mathrm{ha}$ of agri-lime. Adhikary (2008) also studied the effects of nitrogen on maize inbred (NML-1) and reported that increased seed yield ( $2.85 \mathrm{t} / \mathrm{ha}$ ) was obtained with this variety when supplied with $180 \mathrm{~kg} \mathrm{~N}$ and crop planted at the density of 66,666 plants/ha and crop fertilized along with the recommended dose of $\mathrm{P}$ and $\mathrm{K}$ fertilizers. Series of experiments were conducted to evaluate the effects of fertilizers on different maize genotypes during the years 2009 and 2010. The results revealed that the highest grain yield of $6.28 \mathrm{t} / \mathrm{ha}$ was produced by the S99TLYQ-B when the crop was fertilized with 120: $60: 40 \mathrm{~kg} \mathrm{~N}, \mathrm{P}_{2} \mathrm{O}_{5}$ and $\mathrm{K}_{2} \mathrm{O} / \mathrm{ha}$ and $10 \mathrm{t} / \mathrm{ha}$ of compost (NARC, 2010). Hence, balanced dose of fertilizers is needed to increase the crop yield of maize in acid soils. The number of fertilizers to be applied in maize depends largely on the genotypic makeup of plants.

The objective of these experiments were to study the response of fertilizer nutrients at different levels on the different maize genotypes in the soil condition of Rampur, Chitwan, Nepal.

\section{Materials and Methods}

\section{Experimental site}

The site was located in central Nepal at $27^{\circ} 40^{\prime} \mathrm{N}$ latitude and $84^{\circ} 19^{\prime} \mathrm{E}$ longitude with an elevation of $228 \mathrm{~m}$ above mean sea level and had a subtropical climate (NMRP, 2011). Maize was planted on sandy silt loam, acidic soil ( $\mathrm{pH}$ 5.54). Fertilizer was applied in the form of Urea, di-ammonium phosphate (DAP), and murate of potash (MoP). Entire dose of DAP and MoP were applied at the time of sowing while half of the urea was first top-dressed at the knee-high stage and second top-dressed at tasseling stage. The average data derived from both years on maximum temperature ranged from 21.95 (January) to 36.35 OC (April), the minimum temperature varied from 9.4 (January) to 24.65 OC (October). There is no rainfall in 
November and January, minimum rainfall $(1.1 \mathrm{~mm})$ occurred in January and maximum rainfall occurred in $99.35 \mathrm{~mm}$ (April). Similarly, average data on relative humidity showed that minimum humidity (76.8\%) occurred in April and maximum relative humidity (99\%) occurred in December. The details of weather data of individual year were shown in Table 2.

Table 1. Monthly mean weather condition during crop growing season (October-April) in 2009/10 and 2010/11 winter seasons at Rampur, Chitwan, Nepal

\begin{tabular}{|c|c|c|c|c|c|c|c|c|}
\hline \multirow[t]{2}{*}{ Month } & \multicolumn{2}{|c|}{$\begin{array}{l}\text { Maximum } \\
\text { temperature (OC) }\end{array}$} & \multicolumn{2}{|c|}{$\begin{array}{l}\text { Minimum } \\
\text { temperature (OC) }\end{array}$} & \multicolumn{2}{|c|}{ Rainfall (mm) } & \multicolumn{2}{|c|}{$\begin{array}{l}\text { Relative humidity } \\
\text { (\%) }\end{array}$} \\
\hline & $2009 / 10$ & $2010 / 11$ & $2009 / 10$ & $2010 / 11$ & $2009 / 10$ & $2010 / 11$ & $2009 / 10$ & $2010 / 11$ \\
\hline October & 31.4 & 31.4 & 26.5 & 22.8 & 101 & 48.6 & 97.0 & 97.5 \\
\hline November & 27.1 & 27.1 & 21.6 & 17.0 & 0.0 & 0.0 & 99.0 & 98.8 \\
\hline December & 24.0 & 24.0 & 16.0 & 9.1 & 2.2 & 0.0 & 99.0 & 99.0 \\
\hline January & 20.0 & 23.9 & 10.3 & 8.5 & 0.0 & 0.0 & 94.6 & 100.5 \\
\hline February & 25.4 & 26.1 & 11.9 & 15.1 & 0.0 & 34.9 & 89.5 & 96.3 \\
\hline March & 33.1 & 31.1 & 19.1 & 18.9 & 0.0 & 34.4 & 82.2 & 83.2 \\
\hline April & 38.1 & 34.6 & 23.3 & 19.6 & 165 & 33.7 & 75.4 & 78.2 \\
\hline
\end{tabular}

*Source: (NMRP, 2011)

\section{Experimental design, treatments and crop management}

This experiment was conducted at the farm of National Maize Research Program, Rampur, Chitwan, Nepal during the winter season of the year 2009/10 and 2010/11. The crop was planted in October and harvested in April. Twenty four treatment combinations consisting of six levels of fertilization and four maize genotypes were replicated three times and laid out in a randomized complete block design. The details of the treatment combinations are given in the following Table 1 . Row to row spacing $75 \times 25 \mathrm{~cm}$ was maintained. The net harvested area was $7.2 \mathrm{~m}^{2}$. The gross plot size was $12 \mathrm{~m}^{2}$.

Table 2. The details of the treatments used in experiment in 2009/10 and 2010/11 winter seasons at Rampur, Chitwan, Nepal

\begin{tabular}{ll}
\hline Genotypes & Fertilizer rates \\
\hline V1= Rampur Composite & F1=Control (Zero fertilizer) \\
V2= Manakamana-4 & F2=FYM @ $10 \mathrm{t} / \mathrm{ha}$ \\
V3=Across9942 $\times$ Across9944 & F3=FYM@ $10 \mathrm{t} / \mathrm{ha}$ plus 60:30 $20 \mathrm{~kg}$ NPK/ha \\
V4= S99TLYQ-B & F4=FYM@ $10 \mathrm{t} / \mathrm{h}$ a plus $120: 60: 40 \mathrm{~kg}$ NPK/ha
\end{tabular}


F5=FYM@ 10 t/ha plus 180: 90: 60 kg NPK/ha

F6= 120: $60: 40 \mathrm{~kg} \mathrm{NPK} / \mathrm{ha}$

\section{Data recorded}

Observations were taken on plant height, ear height, cob length, no. of Kernel rows per cob, no. of kernels per rows, and grain yield. Plant height and ear height were recorded at just near to harvesting and the rest of the data were recorded after harvesting. At maturity, central two rows from each the plot were separately harvested and the fresh ear weight was measured in each plot. Grain yield ( $\mathrm{kg} / \mathrm{ha}$ ) at $15 \%$ moisture content was calculated using fresh ear weight with the help of the below formula given by Carangal et al. (1971), Shrestha et al. (2019) and Upreti et al. (2020).

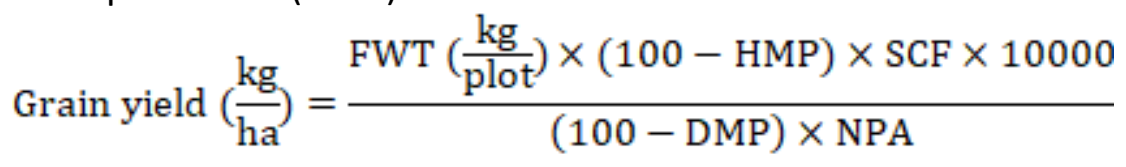

Where,

FWT : Fresh weight of ear in kg per plot at harvest

HMP : Grain moisture percentage at harvest

DMP : Desired moisture percentage, i.e. 15\%

NPA : Net harvest plot area, $\mathrm{m} 2$

SCF : Shelling coefficient, i.e. 0.8

\section{Statistical analysis}

Data were statistically analyzed. Analysis of variance for all data was analyzed using the MSTAT computer program. The significant differences between genotypes were determined using the least significant difference (LSD) test at $1 \%$ or $5 \%$ level of significance (Gomez and Gomez 1984; Shrestha, 2019).

\section{Results and Discussion}

The interaction between different fertilizer levels and varieties on grain yield showed that the highest grain yield ( $5195 \mathrm{~kg} / \mathrm{ha}$ ) was obtained in Rampur Composite followed by Manakamana-4 (5074 kg/ha) and Across9942 × Across9944 (5052 kg/ha) under treatment of application of NPK 180: 90: $60 \mathrm{~kg} / \mathrm{ha}$ plus FYM $10 \mathrm{t} / \mathrm{ha}$. Similarly, S99TLYQ-B produced the highest grain yield (4789 kg/ha) under the same level of fertilization (Figure 1). 


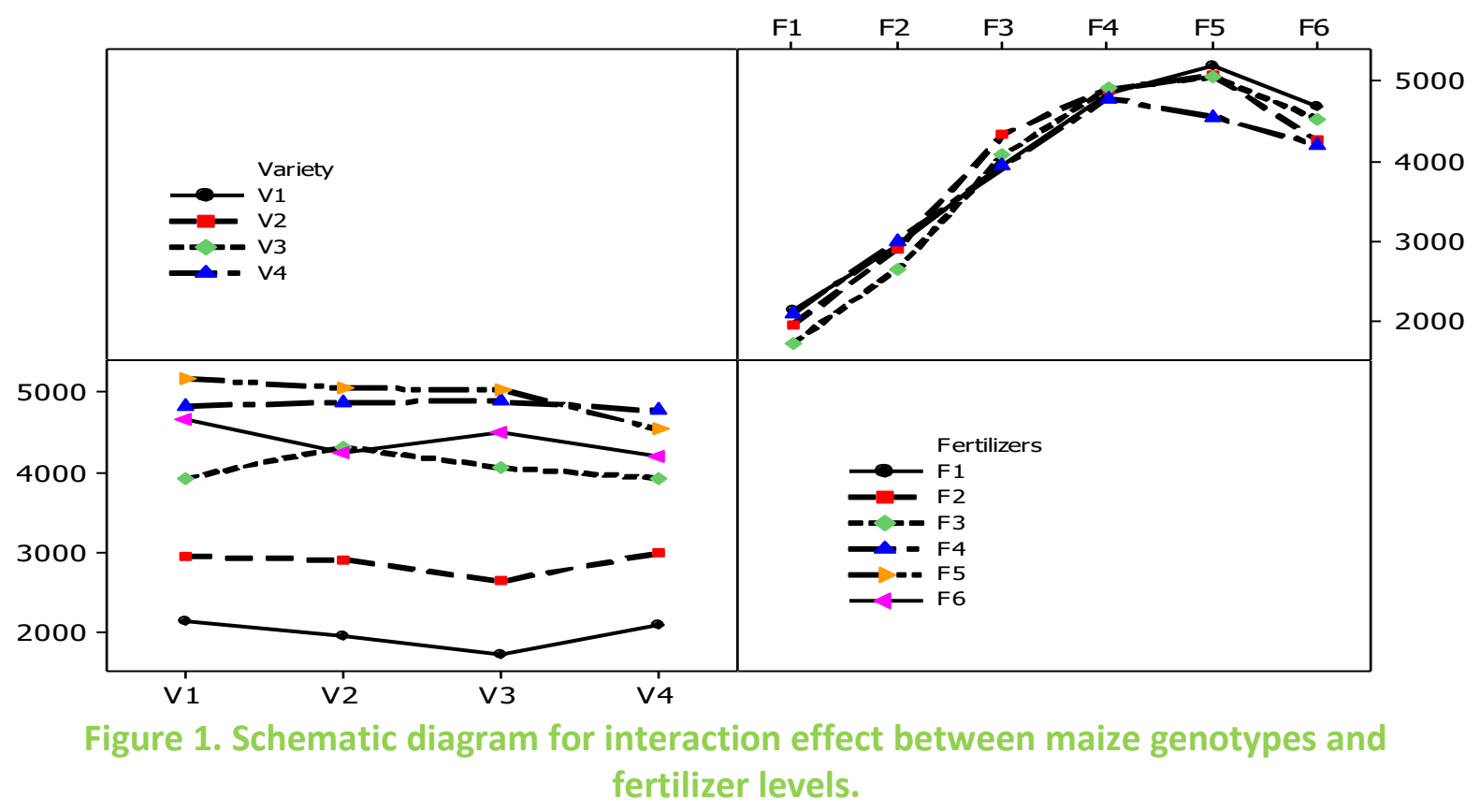

The increasing amount of nitrogen and phosphorus fertilizer application increased yield attributing traits in maize. The highest yield attributing traits namely cob length, no. of kernel rows per cob and no. of kernels per kernel rows were found under the level of fertilization (180:90:60 kg NPK plus 10 t FYM/ha) in Rampur Composite, Manakamana-4, Across9942 × Across9944. Gokmen et al. (2001) and Wajid et al. (2007) reported that 1000 grain weight increased with increasing N levels. Gungula et al. (2007) and Dawadi (2009) observed a number of kernels/ear and number kernel rows/cob increased with increasing nitrogen levels. The increase in 1000-grain weight with increasing P levels might be due to improvement in the source-sink relationship. These results are supported by the findings of Ahmad (1989) and Toor (1990).

Table 3. Effect of different level of manures and fertilizers on different maize genotypes in 2009/10 and 2010/11 winter seasons at Rampur, Chitwan, Nepal

\begin{tabular}{llllllllcc}
\hline $\begin{array}{c}\text { Treatme } \\
\text { nts }\end{array}$ & $\begin{array}{c}\text { Cob length } \\
(\mathrm{cm})\end{array}$ & \multicolumn{2}{c}{$\begin{array}{c}\text { Kernel rows per } \\
\text { cob (No.) }\end{array}$} & \multicolumn{2}{c}{$\begin{array}{c}\text { Kernel per kernel } \\
\text { row (No.) }\end{array}$} & \multicolumn{2}{c}{$\begin{array}{c}\text { Grain yield } \\
\text { (kg/ha) }\end{array}$} \\
\cline { 2 - 10 } & $2009 / 10$ & $2010 / 11$ & $2009 / 10$ & $2010 / 11$ & $2009 / 10$ & $2010 / 11$ & $2009 /$ & $2010 /$ \\
& & & & & & & & 10 & 11 \\
\hline V1F1 & 11.4 & 9.66 & 10.7 & 10.4 & 22.6 & 14.86 & 2860 & 1443 \\
V1F2 & 12.2 & 11.6 & 12 & 11.93 & 24.2 & 17.53 & 3740 & 2180 \\
V1F3 & 13.8 & 14.13 & 12.8 & 13.6 & 31.1 & 28.33 & 4960 & 2927 \\
V1F4 & 14.1 & 14.46 & 13 & 13.86 & 30.5 & 30.4 & 5840 & 3863 \\
V1F5 & 14.2 & 15.13 & 13.1 & 14 & 31.9 & 30.8 & 6260 & 4130 \\
V1F6 & 13.8 & 13.86 & 12.6 & 13.73 & 29.1 & 29.46 & 5630 & 3733 \\
V2F1 & 10.4 & 9.06 & 11.5 & 10 & 21.1 & 15.53 & 2240 & 1677 \\
V2F2 & 11.7 & 11.6 & 13.3 & 11.7 & 25.3 & 21.86 & 3830 & 2010 \\
V2F3 & 13.8 & 14.6 & 15.2 & 13.4 & 28.5 & 30.2 & 5340 & 3333 \\
V2F4 & 14.3 & 14.73 & 15.3 & 13.86 & 30.2 & 31 & 5960 & 3837 \\
\hline
\end{tabular}




\begin{tabular}{|c|c|c|c|c|c|c|c|c|}
\hline V2F5 & 14.9 & 14.86 & 15.5 & 14.26 & 31.7 & 31.73 & 5990 & 4157 \\
\hline V2F6 & 14.2 & 13 & 15.1 & 12.93 & 30.7 & 27.2 & 5280 & 3240 \\
\hline V3F1 & 9.7 & 8.33 & 11.7 & 9.2 & 19.7 & 13.8 & 2300 & 1163 \\
\hline V3F2 & 11.6 & 10.8 & 13.7 & 11.53 & 25.5 & 21.13 & 3360 & 1953 \\
\hline V3F3 & 12.6 & 13.2 & 15.7 & 12.03 & 29.3 & 30.4 & 5120 & 3033 \\
\hline V3F4 & 13.3 & 13.66 & 15.7 & 13.33 & 28.8 & 29 & 6190 & 3630 \\
\hline V3F5 & 13.4 & 13.93 & 16.3 & 13.43 & 30.9 & 29.53 & 6280 & 3823 \\
\hline V3F6 & 13.2 & 13.2 & 15.1 & 13.16 & 29.1 & 28.23 & 5770 & 3290 \\
\hline V4F1 & 9.9 & 7.2 & 11.6 & 9.33 & 20.7 & 12.66 & 2750 & 1460 \\
\hline V4F2 & 11.7 & 10.2 & 13.5 & 10.13 & 25 & 20.06 & 3920 & 2083 \\
\hline V4F3 & 14.3 & 13.53 & 14.9 & 12.26 & 28.3 & 25.4 & 4990 & 2890 \\
\hline V4F4 & 14.9 & 13.73 & 15.2 & 12.13 & 32.5 & 29.73 & 5740 & 3380 \\
\hline V4F5 & 13.9 & 13.13 & 14.9 & 12.53 & 30.5 & 26.06 & 5760 & 3817 \\
\hline V4F6 & 14.1 & 13.4 & 14.9 & 12.03 & 29.1 & 28.6 & 5280 & 3140 \\
\hline Mean & 13 & 12.54 & 13.9 & 12.28 & 27.8 & 25.14 & 4810 & 2925 \\
\hline CV(\%) & 4.62 & 9.36 & 7.52 & 7.99 & 6.25 & 14.63 & 15.32 & 17.44 \\
\hline $\begin{array}{l}\text { F-test } \\
\text { (V) }\end{array}$ & $* *$ & $* *$ & $* *$ & $* *$ & Ns & $\mathrm{Ns}$ & Ns & $\mathrm{Ns}$ \\
\hline$(F)$ & $* *$ & $* *$ & $* *$ & $* *$ & $* *$ & $* *$ & $* *$ & $* *$ \\
\hline$(V \times F)$ & Ns & Ns & Ns & Ns & Ns & Ns & Ns & Ns \\
\hline $\begin{array}{l}\text { LSD } \\
(0.05)\end{array}$ & 0.402 & 0.788 & 0.701 & 0.658 & 1.428 & 2.468 & 605 & 419 \\
\hline
\end{tabular}

**Highly significant at 0.01 level, *Significant at 0.05 level and Ns: non-significant.

In 2009/10 and 2010/11, the effect of genotypes was observed to be non-significant whereas the effect of fertilizers was found to be highly significant. The increasing amount of fertilizer up to $180 \mathrm{~N} \mathrm{~kg} / \mathrm{ha}$, phosphorus $90 \mathrm{~kg} / \mathrm{ha}$, and potassium $60 \mathrm{~kg} / \mathrm{ha}$ increased the grain yield in both years. Singh et al. (2000) indicated that grain increased with the increase in nitrogen level from 0-200 kg/ha. Khan et al. (2014) found an increasing amount of phosphorus increased the grain yield of maize at a constant level of $150 \mathrm{~N} \mathrm{~kg} / \mathrm{ha}$ application; the maximum grain yield (5356 kg/ha) was recorded in Jalal variety when it was fertilized with 150:100 N:P $\mathrm{kg} / \mathrm{ha}$. In 2009/10 the highest grain yield (6068 kg/ha) was obtained at the highest level of fertilization (180:90:60 NPK kg/ha plus FYM $10 \mathrm{t} / \mathrm{ha}$ ). The variety Rampur composite produced highest grain yield (4882 kg/ha) followed by Across9942 × Across $9944(4837 \mathrm{~kg} / \mathrm{ha}$ ) and Manakamana-4 (4773 kg/ha) Similarly in 2010/11, grain yield was increased with an increased level of fertilization. The highest grain yield $(3873 \mathrm{~kg} / \mathrm{ha}$ ) was obtained the highest level of fertilization (180:90:60 NPK kg/ha plus FYM $10 \mathrm{t} / \mathrm{ha}$ ). The variety Rampur composite produced highest grain yield (3046 kg/ha) followed by Manakamana-4 (3042 kg/ha) and Across9942 × Across 9944 (2816 kg/ha) (Table 4). 
Table 4. Grain yield under different fertilizer levels and genotypes in 2009/10 and 2010/11 winter seasons at Rampur, Chitwan, Nepal

\begin{tabular}{lll}
\hline Treatments & \multicolumn{2}{c}{ Grain yield (kg/ha) } \\
\hline Fertilizer levels & $2009 / 10$ & $2010 / 11$ \\
\hline F1 (Control) & 2538 & 1436 \\
F2 (FYM 10 t /ha) & 3713 & 2057 \\
F3 (60:30:20 NPK plus FYM 10t/ha) & 5103 & 3046 \\
F4 (120:60:40 NPK plus FYM 10t/ha) & 5938 & 3787 \\
F5 (180:90:60 NPK kg/ha plus FYM 10 & 6068 & 3873 \\
t/ha) & & \\
F6 (120:60:40 NPK kg/ha) & 5490 & 3351 \\
CV(\%) & 15.32 & 17.4 \\
F-test & $* *$ & $* *$ \\
LSD (0.05) & 221.5 & 419.1 \\
Genotypes & & \\
V1 (Rampur Composite) & 4882 & 3046 \\
V2 (Manakamana-4) & 4773 & 3042 \\
V3 (Across9942 $\times$ Across9944) & 4837 & 2816 \\
V4 (S99TLYQ-B) & 4740 & 2795 \\
CV(\%) & 15.32 & 17.4 \\
F-test & Ns & Ns \\
LSD (0.05) & 605 & 342.2 \\
\hline
\end{tabular}

**Highly significant at 0.01 level, *Significant at 0.05 level and ns, non-significant.

\section{Conclusions}

The study showed that maize genotypes namely Rampur Composite, Manakamana-4, Across9942 $\times$ Across 9944 and S99TLYQ-B produced higher grain yield of 5195, 5074, 5052 and $4789 \mathrm{~kg} / \mathrm{ha}$ respectively with the application of NPK @ 180: 90: $60 \mathrm{~kg} / \mathrm{ha}$ plus FYM 10 $\mathrm{t} / \mathrm{ha}$. Similarly, produced the highest grain yield $(\mathrm{kg} / \mathrm{ha})$. The yield attributing traits namely cob length, no. of kernel rows per cob and no. of kernels per kernel rows were found higher at the fertilization rate of 180: 90: $60 \mathrm{~kg}$ NPK/ha plus FYM $10 \mathrm{t} /$ ha so such fertilization rate is suitable for maize varieties at Rampur, Chitwan, Nepal during winter seasons.

\section{Acknowledgements}

The authors would also like to thank National Maize Research Program Rampur (NMRP), Rampur, Chitwan, Nepal for the provision of research materials financial supports for conducting this research.

\section{References}

Adhikary, B.H. 2008. Effect of nitrogen on inbred maize seed production planted at varying densities in the acidic soil at Rampur, Chitwan. In: Proc. Of the Abstracts. The Fifth National Conference on Science and Technology. Nepal Academy of Science and Technology (NAST), Nov. 10-12, 2008. Kathmandu, Nepal, P. 19. 
Adhikary, B.H., Gauli, R.C. \& BC, B.B. 2001. Effects of manures and fertilizers on the grain production of maize in rotation with cowpea in acid soils of Malepatan, Pokhara. In: Proc. of an International Maize Symposium. Sustainable maize production Systems for Nepal, held December 3-5, 2001, Kathmandu, Nepal, Pp. 160-162.

Adhikary, B.H., Pandey, B.R. \& Neupane, D.D. 2007. Increased productivity of maize genotypes through the use of inorganic fertilizers and agricultural lime in the Western hills of Nepal. In: Proc. Of the 25th National Summer Crops Research Workshop, held 21-23 June, 2007. NARI, NARC, Khumaltar, Lalitpur, Nepal, Pp. 225-230.

Adhikary, B.H. \& Ranabhat, D.B. 2004. An economic perspective of manures and fertilizer application on maize. Pp.. In: Proc. Of the 24th National Summer Crops Research Workshop on maize Research and Production in Nepal, organized by Nepal Agriculture Research Council (NARC) and NMRP, held June 28-30, 2004, Kathmandu, Nepal, Pp. 287-290.

Ahmad, I. 1989.The effect of phosphorus application in different proportions with nitrogen on the growth and yield of maize. M.Sc. (Hons.) Agri. Thesis, Dep. of Agron. Univ. of Agric. Faisalabad- Pakistan.

Baral, B.R., Adhikari, P., \& Shrestha, J. (2015). Growth and yield response of hybrid maize (Zea mays L.) to phosphorus levels in sandy loam soil of Chitwan valley, Nepal. International Journal of Environmental Science, 4(2): 147-156.

Carangal, V.R., Ali, S.M., Koble, A.F., Rinke, E.H. \& Sentz, J.C. 1971. Comparison of S1 with testcross evaluation for recurrent selection in maize. Crop Science, 11: 658-661.

Dawadi, D.R. 2009. Response of maize hybrids to different plant density and nitrogen levels in inner terai environment during winter season, M.S. Thesis, Institute of Agriculture and Animal Science, Rampur, Nepal, 154 p.

Gokmen, S., Sencar, O. \& Sakin, M.A. 2001. Response of popcorn (Zea mays L.) to nitrogen rates and plant densities. Turkish J. of Agri. And Forestry, 25:15-23

Gomez, K.A. \& Gomez, A.A. 1984. Statistical procedures for agricultural research. 2nd edn.International Rice Research Institute, College, Laguna, pp. 680.

Gungula, D.T., Togun, A.O. \& Kling, J.G. 2007. The effect of nitrogen rates on phenology and yield components of early maturing maize cultivars. Glob. J. Pur. App. Sci., 13:319- 324.

Joshy, D. 1997. Soil fertility and fertilizer use in Nepal. Soil Science Division, NARC, Khumaltar, Lalitpur, Nepal, 82.

Khan, F., Khan, S., Fahad, S., Faisal, S., Hussain, S., Ali, S. \& Ali, A. 2014.Effect of Different Levels of Nitrogen and Phosphorus on the Phenology and Yield of Maize Varieties. American Journal of Plant Sciences, 5: 2582-2590.

MoALD. 2018. Statistical information on Nepalese agriculture, Ministry of Agriculture and Livestock Development (MoALD), Singh Durbar, Kathmandu, Nepal.

NARC. 2010. Soil fertility research highlights In: Annual Report for the year 2005/06. National Maize Research Programme (NMRP), NARC, Rampur, Chitwan, Nepal.

NMRP.2011.Annual Report 20010/11. National Maize Research Program, Rampur, Chitwan, Nepal. 
Regmi, A.P., Ladha, J.K., Pasuquin, E., Pathak, H., Hobbs, P.R., Shrestha, L.L., Gharti, D.B., Duveiller, $E$. The role of potassium in sustaining yields in a long-term rice-wheat experiment in the Indo-Gangetic plains of Nepal. Biol. Fert. Soils, 2002, 36: 240-247.

Shrestha, J. 2020. P-Value: A True Test of Significance in Agricultural Research, https://www.linkedin.com/pulse/p-valuetest-significance-agricultural-researchjibanshrestha/

Shrestha, J., Subedi, S., Timsina, K.P., Gairhe, S., Kandel, M. \& Subedi, M. 2019. Maize research. New India Publishing Agency (NIPA), New Delhi-34, India.

Singh, D.P., Rana, N.S. \& Singh, R.P. 2000. Growth and yield of winter maize (Zea mays L.) as influenced by intercrops and nitrogen application. Ind. J. Agron., 45: 515-519.

Toor, S.A. 1990. Effect of NPK application on the growth and yield of new maize genotypes planted in two geometrical pattern. M.Sc. (Hons.) Agri. Thesis, Dept. of Agron; university of Agriculture, Faisalabad- Pakistan.

Upreti, J., Acharya, P., Upadhyaya, J. \& Shrestha, J. 2020. Heterosis in maize hybrids at farmer's field in Dang district of Nepal. Fundamental and Applied Agriculture, 5(2): 188-193.

Wajid, A., Ghaffar, A., Maqsood, M., Hussain, K. \& Nasim, W. 2007. Yield response of maize hybrids to varying nitrogen rates. Pak. J. Agri. Sci., 44: 217-220. 